\title{
A Low-Cost Vision System in Determination of a Robot End-Effector's Positions
}

\author{
Wojciech Lisowski, Piotr Kohut \\ AGH University of Science and Technology, Faculty of Mechanical Engineering and Robotics, Al. Mickiewicza 30, 30-059 Kraków
}

\begin{abstract}
Vision systems are commonly used in robotics. The most often, they are applied as sensory systems, but they can also be used for experimental determination of a manipulator end-effector's pose. In this paper, application of an exemplary low-cost vision system for position measurement was tested. The considered vision system was composed of a pair of CMOS cameras. The applied experiment procedure consisted in recording of a set of pictures captured after consequent approaches of a robot end-effector (grasping a cube with markers on it) to the command pose repeatedly from the same direction. Processing of the pictures led to determination of position of the markers. Analysis of position measurement precision contained: determination of spatial distribution of consequently captured positions, assessment of quality of the captured pictures according to a set of 4 indicators, and comparison of measurement techniques employing the considered vision system and a professional measurement system (for this purpose the experiment was repeated with use of a laser tracker and a local estimate of the unidirectional positioning repeatability RP was determined). The reported investigation indicated that low-cost stereovision systems might be successfully applied for a robotic manipulator position measurement with accuracy of approximately $0.1 \mathrm{~mm}$, which is often satisfactory in the engineering practice. Surprisingly, analysis of the achieved experimental results led to reasonable estimation of the RP value (approx. $0.02 \mathrm{~mm}$ according to the robot's manufacturer).
\end{abstract}

Keywords: manipulating robots, vision systems, measurement of an end-effector position, positioning repeatability WUINU

\section{Introduction}

Satisfactory precision of industrial manipulating robots is a condition for achieving the expected quality of the robots' operation. Parameters that characterize robot precision are defined by the standard [7]. Assessment of the robotic manipulators' precision bases on their end-effector pose measurement. That is why the appropriate pose measurement system is necessary to make the assessment possible.

Currently, two types of such the measurement systems are used in engineering practice [1]. These are either laser trackers or vision systems. Originally, the laser trackers performed only the incremental measurement based on application of an interferometer and leading to determination of variation of the distance between

Autor korespondujący:

Wojciech Lisowski, lisowski@agh.edu.pl

Artykuł recenzowany

nadesłany 13.01.2017 r., przyjęty do druku 06.03.2017 r. the sensor and the end-effector. Later, the indirect distance determination method basing on measurement of the 'time of flight' of the light beam or on analysis of phase of a set of the single-frequency components of the reflected light beam traveling between the sensor and the end-effector, there and back, were introduced. In case of the vision systems a set of linear cameras, of pre-calibrated mutual locations, proved to be the most effective in this kind of measurements. The accuracy of the considered measurement varies between $0.01 \mathrm{~mm}$ and $0.05 \mathrm{~mm}$ per $1 \mathrm{~m}$ of the distance between the measuring device and the robot end effector. The precision of the measurement is limited mainly by tolerances of manufacturing and assembly of mechanical parts of the measuring devices, as well as by the achievable time of buildup of the response signal of optical sensors used in case of the measurement carried out during motion of a manipulator.

The measurement of the end-effector pose is directly used by robots' manufacturers in manufacturing quality control procedures. The robots' users the most often carry out the measurement of position to determine the positioning repeatability [7] of the robot or to perform the external calibration of the robots [1]. The positioning repeatability is the most important precision type parameter of the manipulating robots. The external calibration is conducted with respect to the Cartesian reference coordinate frame and it aims at improvement of the manipulating robots' positioning accuracy.

It should be noted that the advanced pose measurement services as well as a purchase of the position measuring devi- 


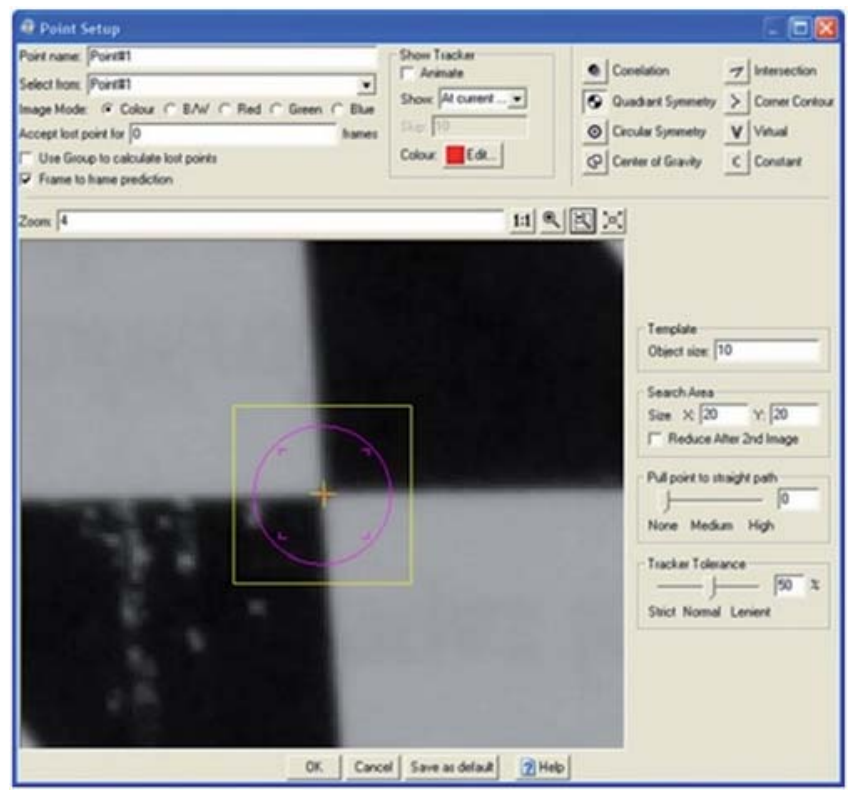

Fig. 4. Quadrant symmetry adjustment

Rys. 4. Ustawienia modułu śledzenia „quadrant symmetry”

video material can be analyzed to obtain the trajectories, velocities and accelerations of analyzed markers. The software is equipped with broad set of tools to track markers and advanced post-processing tools.

The developed vision system was calibrated (internally and externally) in compliance with procedures of TEMA software [14]. After system calibration, the next step of the software usage is composed of image sequences reading, image markers tracking employing "quadrant symmetry" method and resulting objects trajectories analysis using TEMA post-processing tools.

The overview of the used test stand is presented in Fig. 1.

The test stand was composed of the following elements:

- a Mitsubishi RV2AJ robot,

-2 digital SLR cameras: Canon EOS 5D Mark II, 21.1

Megapixel, equipped with Canon EF 24-70 mm f/2.8L II

USM lenses,

-2 halogen lamp (500 W each),

- an analyzed object: a cube with stuck markers.

Figure 2 presents the mutual position and orientation of the components of the test stand.

In order to make the processing of the captured pictures possible it was necessary to start with determination of selected internal and external camera parameters estimation $[6$, 15]. Estimation of the internal camera's parameters with lenses' distortion was carried out by means of a flat calibration plate with square patterns [16]. External camera calibration was performed using relative camera orientation procedure implemented in TEMA software [14]. An example result of external camera parameters' estimation is depicted in Fig. 3. An important measure of the quality of the resulting external camera solution is indicated by parallax error, which in this case amounted to a very low value $(0.00537 \mathrm{~mm})$.

After calibration, the actual measurement consisting in capturing the images started.

The next step of the data processing consisted in tracking the points indicated by the markers on the captured images. It was executed employing the quadrant symmetry tracker method [14]. Example of the tracer setting is shown in Fig. 4.

The 3D positions of markers detected on the captured pictures were determined with use of the TEMA software package.

\section{Results of testing}

The experiment consisting in acquisition of series of pictures of the robot end-effector grasping the cube with markers was carried out in the course of the Bachelor thesis activity [10]. Geometrical data (3D positons of markers) obtained in the result of picture analysis were the base for analysis of the achieved experimental results.

In order to assess the properties of the recorded experimental data the analysis of spatial distribution of the positions recorded during the experiment was carried out. The exemplary locations of the identified positions for the measurement point No. 2 (approach in z direction) are presented in Fig. 5.A.

The total (for all measuring points and approach directions) dispersion of positions of the measuring points corresponding to the consequent pictures taken during the first approach (denoted by '+' on the picture) was 36\%-98\% of the dispersion of positions (denoted by 'o') corresponding to the consequent 30 approaches to the command position.

Figure 5.B. presents the exemplary sequence of estimates of the command position evaluated basing on the consequent pictures taken after the first approach to the command position

A
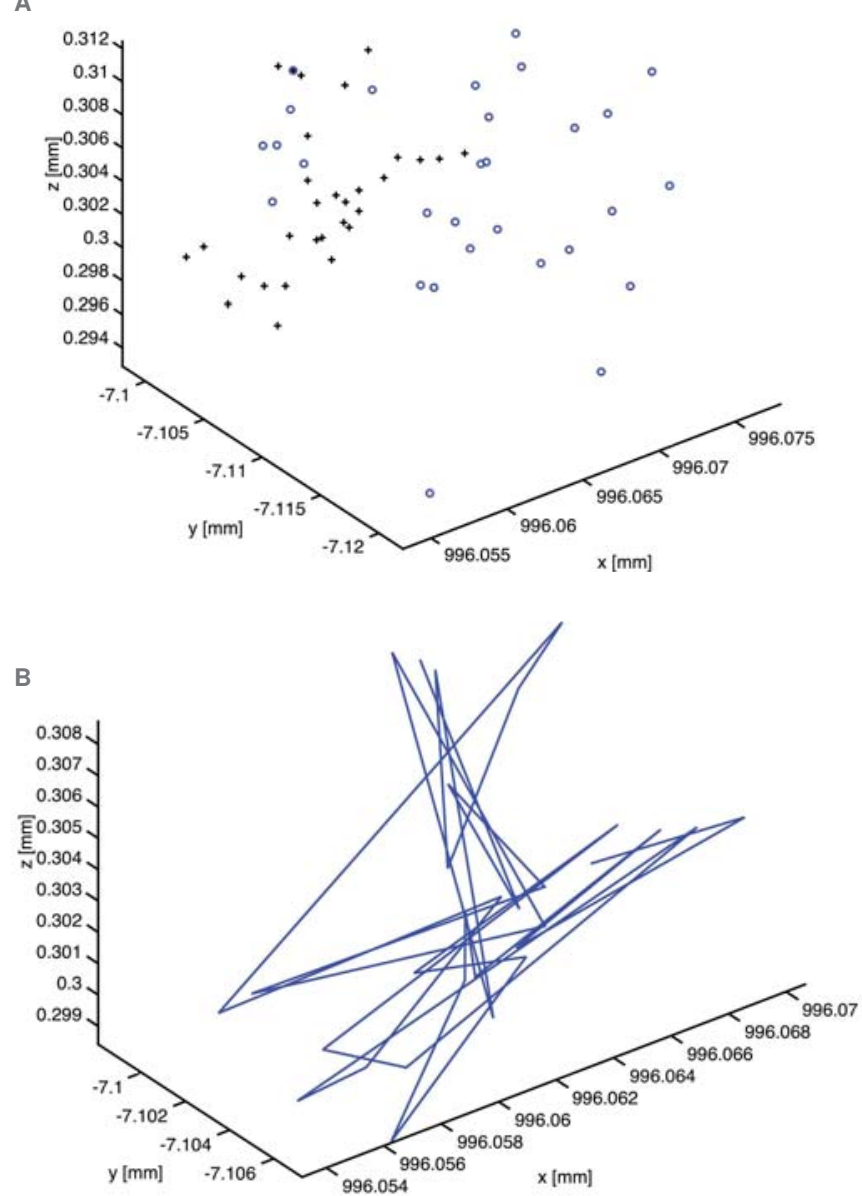

Fig. 5. Distribution of recorded positions (point 2, approach direction z): A. (+) 30 pictures taken during the 1 st approach, (0) the first picture for each of the 30 approaches, B. consequent positions corresponding to 30 pictures of the 1 st approach joined with a straight line segments

Rys. 5. Rozkład przestrzenny zarejestrowanych położeń (punkt nr 2, kierunek zbliżenia z) na podstawie: A. (+) 30 zdjęć wykonanych kolejno w trakcie pierwszego dojścia, (o) pierwszego zdjęcia dla 30 dojść do pozycji zadanej, B. kolejne położenia odpowiadające 30 zdjęciom wykonanym kolejno w trakcie pierwszego dojścia połączone odcinkami linii prostej 


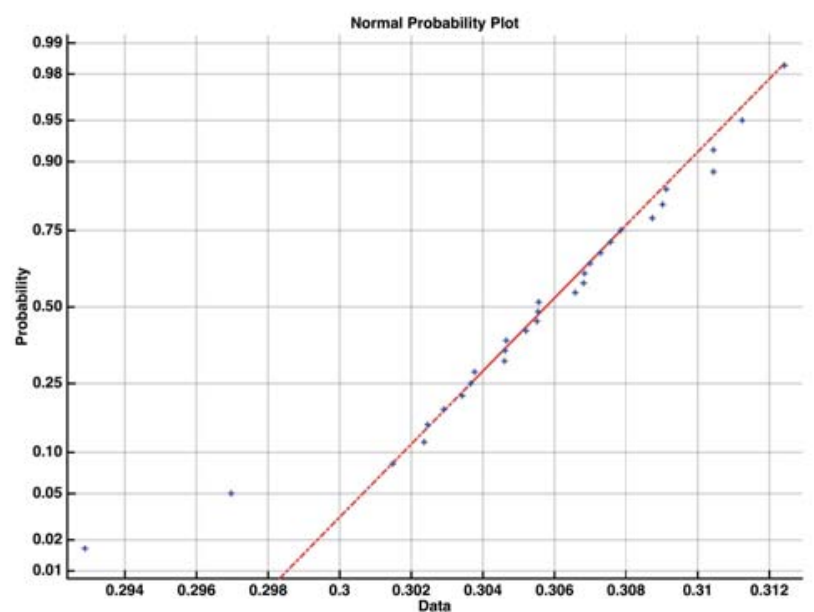

B

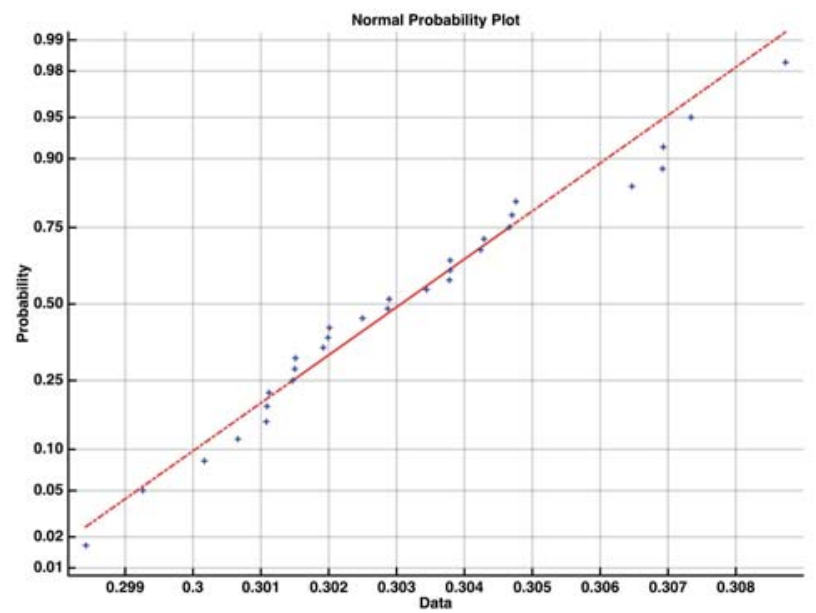

Fig. 6. Normal probability plot of: A. measured positions, B. measurement noise, (point 2, approach direction z) Rys. 6. Wykresy normalności rozkładu prawdopodobieństwa A. pozycje zarejestrowane, B. szum pomiarowy (punkt $\mathrm{nr} 2$, kierunek zbliżenia z)

(consequent positions are connected by a straight line segments forming a broken line). Qualitative assessment of a shape of the broken line from the Fig. 5.B led the authors to the conclusion that the dispersion of the consequent estimates of the positions is considerably irregular, what suggested the random type of the distribution of the considered estimates of the command position.

The analysis showed that the dispersion of the estimates related to the measurement noise was less than dispersion of the estimates of the measured position, but they were of the same order of magnitude of $0.01 \mathrm{~mm}$. The dispersion characterizes the tested measurement system spatial resolution.

In Fig. 6, the result of assessment of randomness of the positions recorded during the conducted experiments is presented. The normal probability plots, which based on quantiles, were used [12] for the assessment.

Qualitative analysis of the above pictures let the authors to the conclusion that the normal plot showed in Fig. 6.A confirmed that, apart from 2 outliers, the other measuring points fitted well the random distribution. Figure 6.B showed that the distribution of the measurement noise was random but it differed a bit more from the normal distribution than distribution of the measured positions.

Figure 7 presents histograms approximating probability density functions of the sets of measuring positions and positions corresponding to measurement noise. Classification into 9 bins was used.

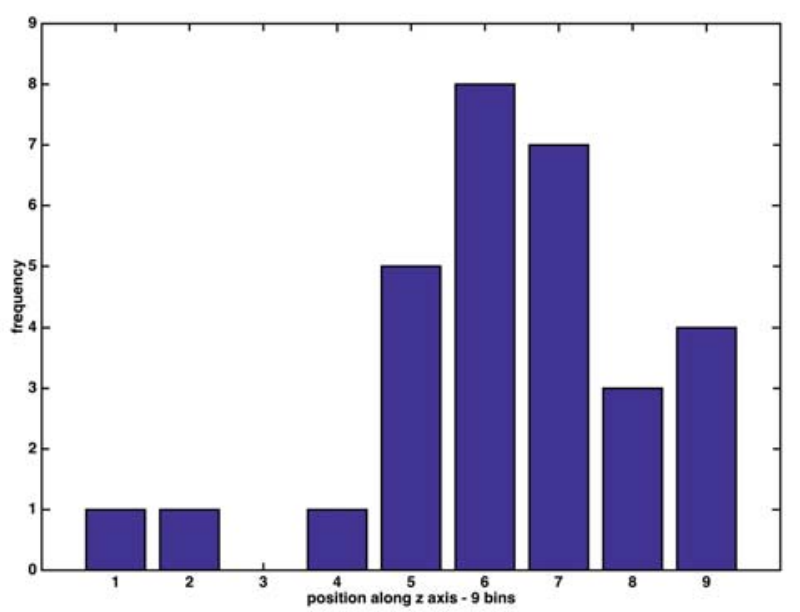

B

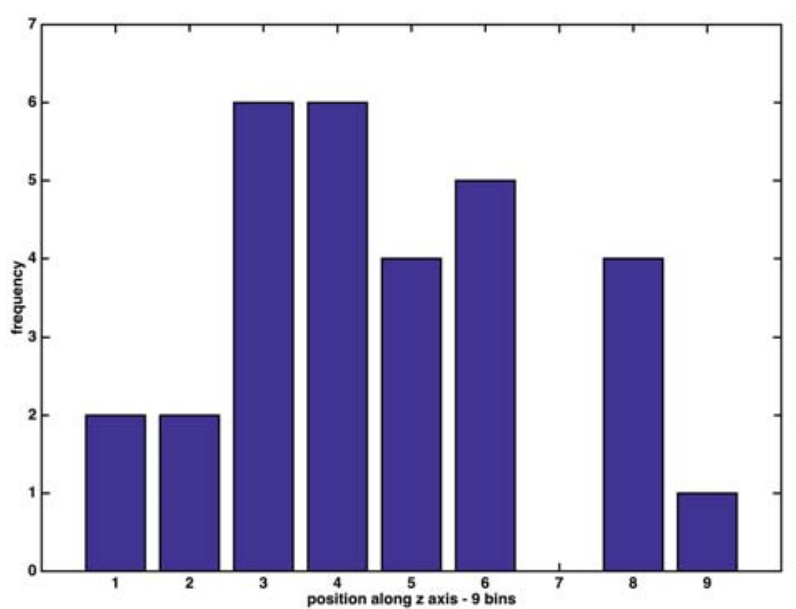

Fig. 7. Histogram of: A. measured positions, B. measurement noise, (point 2, approach direction $\mathrm{z}$ )

Rys. 7. Histogram: A. zarejestrowanych położeń, B. Szumu pomiarowego (punkt nr 2, kierunek zbliżenia z)
The histogram showed in Fig. 7.A qualitatively well corresponds to the normal probability distribution when the mentioned 2 outliers are disregarded. The similarity of the histogram presented in Fig. 7.B to the normal distribution function is smaller, but the presented data may correspond to some random distribution as well.

Basing on the above assessment the authors stated that the spatial distribution of the positions recorded during the experiment as well as the spatial distribution of the measurement errors was of random type close to the normal distribution.

\section{Analysis of position measurement precision}

The properties of the experimental data recorded with use of the low cost stereovision system were analyzed with the aim of characterization of the achieved position measurement precision. The analysis scope covered the following indicators:

- spatial resolution $R_{s}$,

- measurement resolution (including subpixel) $R_{m}$,

- average measurement noise $N_{m a}$,

- theoretical TEMA measurement accuracy $T_{a}$.

The actual experiment was preceded by estimation of position measurement precision of the considered stereovision system. 
Initially, the a priori spatial resolution and the measurement resolution were estimated basing on the stereovision system settings [2]. The following settings were assumed for the analysis (see Fig. 2):

- baseline $1319 \mathrm{~mm}$,

- focal length $69 \mathrm{~mm}$,

- distance between the camera and the analyzed object: $1200 \mathrm{~mm}$,

- subpixel measurement capability $M_{p}=0.1$ pixel (the system's measurement resolution capability in a fraction of a pixel),

- field of view (FOV) $589 \mathrm{~mm} \times 393 \mathrm{~mm}$,

- image resolution $R_{i} 5616 \times 3744$ pixels.

The estimates of the first 2 indicators were obtained with use of the following formulas:

$$
\begin{aligned}
& R_{s}=\frac{F O V}{R_{i}} \\
& R_{m}=R_{s} \cdot M_{p}
\end{aligned}
$$

The obtained values of $R_{s}$ and $R_{m}$ are listed in tab. 1 .

Tab. 1. Estimates of precision of the measurement of position Tab. 1. Estymaty precyzji pomiaru położenia

\begin{tabular}{|c|c|c|}
\hline & $\begin{array}{c}\text { Spatial resolution } \\
R_{s}[\mathrm{~mm} / \mathrm{px}]\end{array}$ & $\begin{array}{c}\text { Subpixel measurement } \\
\text { resolution } \\
R_{m}[\mathrm{~mm}]\end{array}$ \\
\hline plane $(\mathrm{y}-\mathrm{z})$ & 0.12 & 0.012 \\
\hline plane $(\mathrm{x}-\mathrm{z})$ & 0.11 & 0.011 \\
\hline
\end{tabular}

Next, the third indicator, the measurement noise $N_{m a}$, was estimated. Standard deviations were calculated for 30 images acquired by the stereo system. The supposed sources of the noise were:

- fluctuation of illumination,

- cameras' CMOS sensor artifacts,

- errors of the sub-pixel "quadrant symmetry" tracking algorithm [14].

The assessment based on distribution of the position determined for consequent 30 pictures taken for the $1^{\text {st }}$ approach to each target position. The average measurement noise $N_{m a}$ related to the applied vision system was calculated as an average of the standard deviation of the recorded coordinates of the measured positions, and it amounted to $N_{m a}=0.009 \mathrm{~mm}$.

Basing on the values of:

- the quadrant tracker uncertainty $T_{q t u}=0.1 \mathrm{~mm}$,

- the cameras orientation angle: $\alpha=87^{\circ}$, an estimate of the last indicator, the theoretical TEMA measurement accuracy $T_{a}$, was evaluated with use of the formula below [14]:

$$
T_{a}=\frac{1.5 T_{q t u}}{\sin \alpha} M_{p}
$$

The obtained value of the theoretical precision $T_{a}$ was $0.015 \mathrm{~mm}$. The carried out partial analyses showed that the resolution of the considered position measurement was approximately equal to $0.015 \mathrm{~mm}$. That indicated that the considered measurement system could be recommended to measurement of position with accuracy of $0.1 \mathrm{~mm}$ being one order of magnitude greater.

\section{Determination of local estimate of unidirectional positioning repeatability RP}

For estimation of positioning repeatability RP the following formulas were applied [7]. The coordinates of the measuring points were denoted by $x_{i}, y_{i}$ and $z_{i}, \mathrm{i}=1, \ldots, n(n=30)$.

First, the position of the centre of the cluster of recorded positions was determined:

$$
\begin{aligned}
& \bar{x}=\frac{1}{n} \sum_{i=1}^{n} x_{i} \\
& \bar{y}=\frac{1}{n} \sum_{i=1}^{n} y_{i} \\
& \bar{z}=\frac{1}{n} \sum_{i=1}^{n} z_{i}
\end{aligned}
$$

Next, the distances of each of the attained positions from the centre of the cluster were estimated:

$$
l_{i}=\sqrt{\left(x_{i}-\bar{x}\right)^{2}+\left(y_{i}-\bar{y}\right)^{2}+\left(z_{i}-\bar{z}\right)^{2}}
$$

The average distance from the centre of the cluster was calculated as:

$$
\bar{l}=\frac{1}{n} \sum_{i=1}^{n} l_{i}
$$

The estimate of the standard deviation of the distance $l_{i}$ was determined according to the following formula:

$$
S_{l}=\sqrt{\frac{\sum_{i=1}^{n}\left(l_{j}-\bar{l}\right)^{2}}{n-1}}
$$

Finally, an estimate of the positioning repeatability was calculated as:

$$
R P=\bar{l}+3 S_{l}
$$

The RP values were estimated for data acquired during 2 separate experiments with use of either the low-cost vision system or the laser tracker.

\subsection{Estimation of RP for results of measurement with use of the vision system}

Figure 8 presents exemplary measuring data - positions recorded during 30 consequent approaches to the point No. 2 along $\mathrm{z}$ direction.

The detected points are grouped in a regularly shaped cluster, slightly elongated along y axis. The clusters determined for the remaining points, as well as directions of approach, proved to be qualitatively similar. 


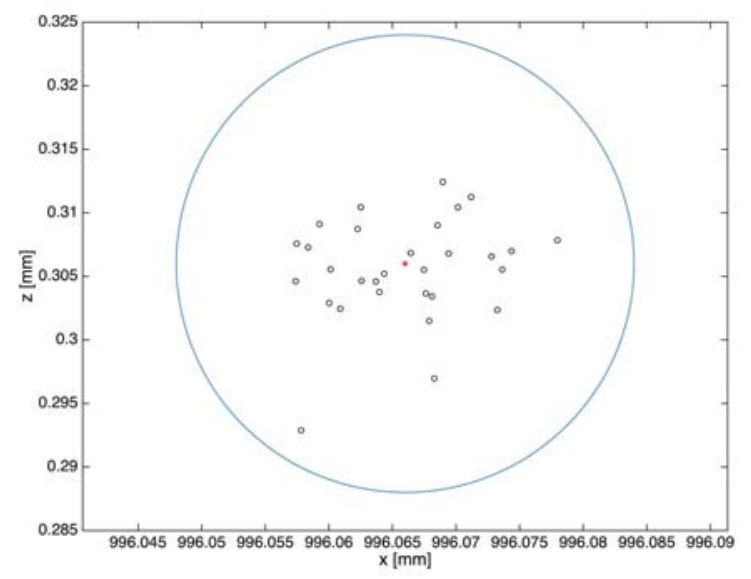

B

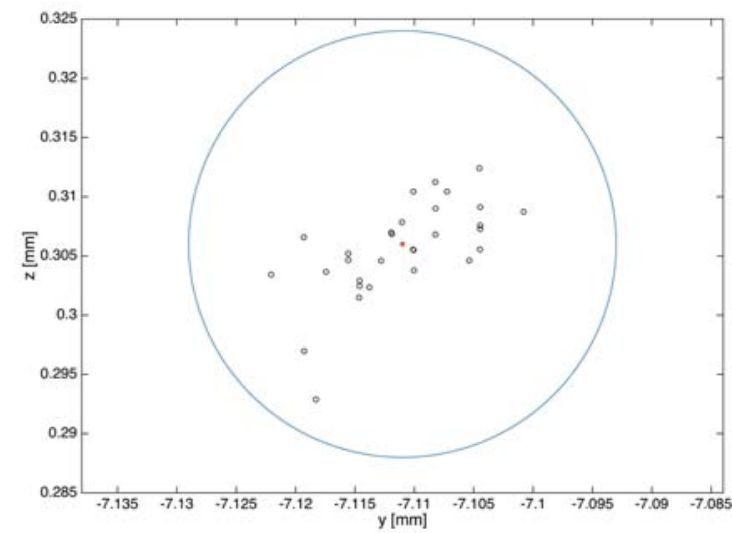

C

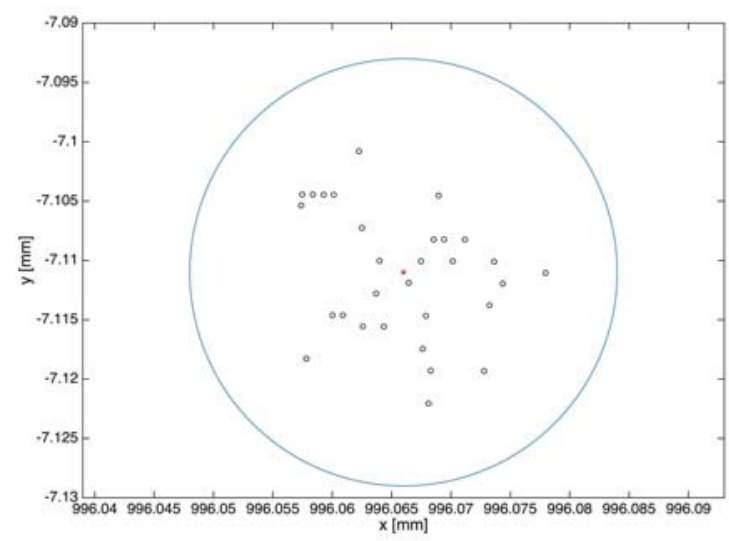

Fig. 8. Positions recorded during the conducted experiment determination for point No. 2 in z direction (o - measured positions, * - indicates the centre position, radius of the circle is equal to $\mathrm{RP}$ ) Rys. 8. Położenia zarejestrowane w czasie przeprowadzonego eksperymentu w punkcie $\mathrm{nr} 2 \mathrm{w}$ kierunku z (o - pozycja zmierzona, * - wskazuje pozycję środkową, promień okręgu odpowiada wartości RP)

The estimated values of RP for all used measuring points and approach directions are presented in tab. 2 .

In Fig. 8 the radius of the presented circle corresponds to RP. The value of RP proved to be visibly greater that the maximum distance of the measured point from the centre of the cluster. All the measured points were located within the sphere of the centre being the centre of the cluster and the radius equal to the estimated $\mathrm{RP}$ value.

The estimated values of RP listed in tab. 2 were compared to the value corresponding to the tested robot type. The listed
Tab. 2. Estimated values of the unidirectional positioning repeatability RP [mm] based on the stereovision system measurement Tab. 2. Wyestymowane wartości jednokierunkowej powtarzalności pozycjonowania RP [mm] wyznaczone na podstawie pomiaru systemem stereowizyjnym

\begin{tabular}{|c|c|c|c|}
\hline Approach directions & $\mathrm{x}$ & $\mathrm{y}$ & $\mathrm{z}$ \\
\hline Point No. 1 & 0.016 & 0.020 & 0.028 \\
\hline Point No. 2 & 0.023 & 0.018 & 0.018 \\
\hline Point No. 3 & 0.017 & 0.023 & 0.014 \\
\hline
\end{tabular}

determined estimates of the RP values vary in the range of $0.014-0.028 \mathrm{~mm}$ which contains a value of $\mathrm{RP}=0.02 \mathrm{~mm}$ (the greatest repeatability error in the whole workspace) reported by the robot's manufacturer. The repeatability depends on position of the end effector in the workspace, so the presence of variation of the RP estimates was in accordance with the engineering practice. Surprisingly, despite the recommended accuracy of measurement of the considered vision system equal to $0.1 \mathrm{~mm}$, the estimation of the RP value was considerably good (mean: $0.02 \mathrm{~mm}$, median: $0.018 \mathrm{~mm}$, and variation $50 \%$ of the mean). The upper bound of the range was greater than the manufacturer's estimate of RP, what might be a result of insufficient accuracy of the used vision system, imperfection of the applied experimental procedure, as well as of wear of the manipulator's mechanisms. The values of RP estimated basing on the conducted experiment results and the RP estimate provided by the robot manufacturer were of the same order of magnitude and considerably close.

Next, the analysis of distribution of the attained positions in space was enhanced. Figure 9 presents 3 sets of 3 spheres. Centres of these spheres are the centre positions calculated for positions recorded during multiple approaches to the command position from each of the 3 perpendicular directions. Radii of the spheres correspond to the RP estimates obtained for each approach direction.

In case of the point No. 1 the spheres are closer to each other than in the case of the points No. 2 and 3 where the spheres corresponding to approach in $\mathrm{x}$ and $\mathrm{z}$ directions are most distant one from the other.

The fourth picture presents the actual distribution of attained poses for the $2^{\text {nd }}$ measuring point. The middle cluster (positions denoted by circles) possessed an outlier on the top. This outlier considerably increased RP represented by the corresponding sphere's radius.

The dependence of the attained end-effector's position on the approach direction is common in practice. The measure of dependence of the attained end-effector position on the approach direction is assessed according to [7] by the multi-directional pose accuracy variation vAP, which is the maximum distance between the sphere centers' pairs. The estimated values of vAP are listed in tab. 3 .

There was no reference value of vAP found for the tested robot. The estimated values of vAP are approximately 2 times greater than the reference RP value, what seems to be a reasonable result.

Tab. 3. Multi-directional positioning accuracy variation vAP [mm] Tab. 3. Wielokierunkowa zmienność dokładności pozycjonowania vAP [mm]

\begin{tabular}{|c|c|c|}
\hline Point No. 1 & Point No. 2 & Point No. 3 \\
\hline 0.038 & 0.046 & 0.052 \\
\hline
\end{tabular}


A

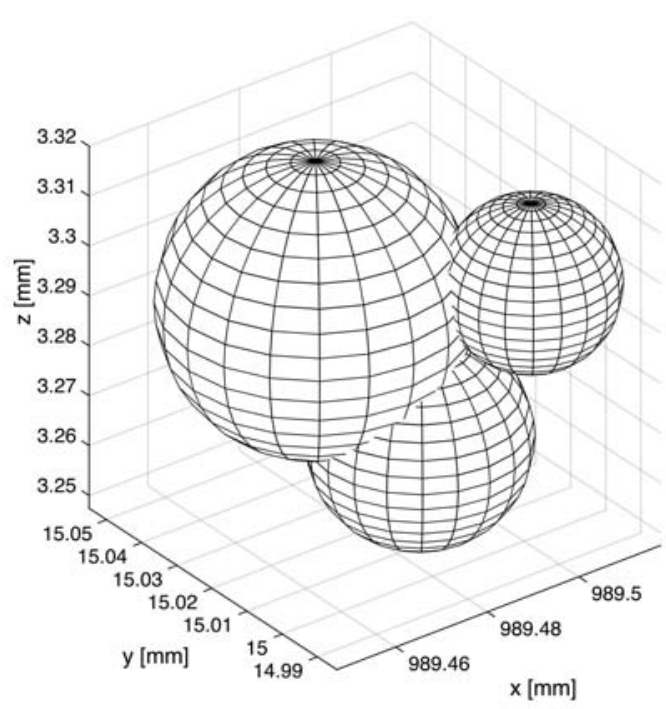

C

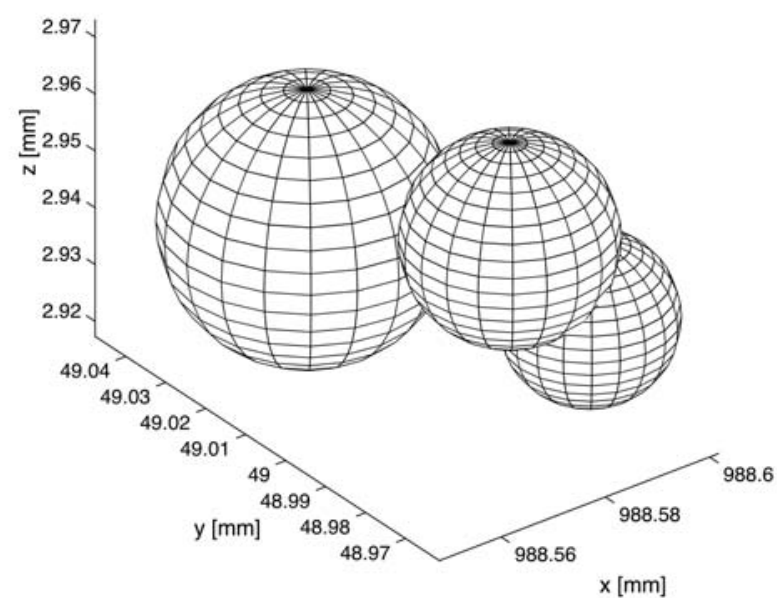

B

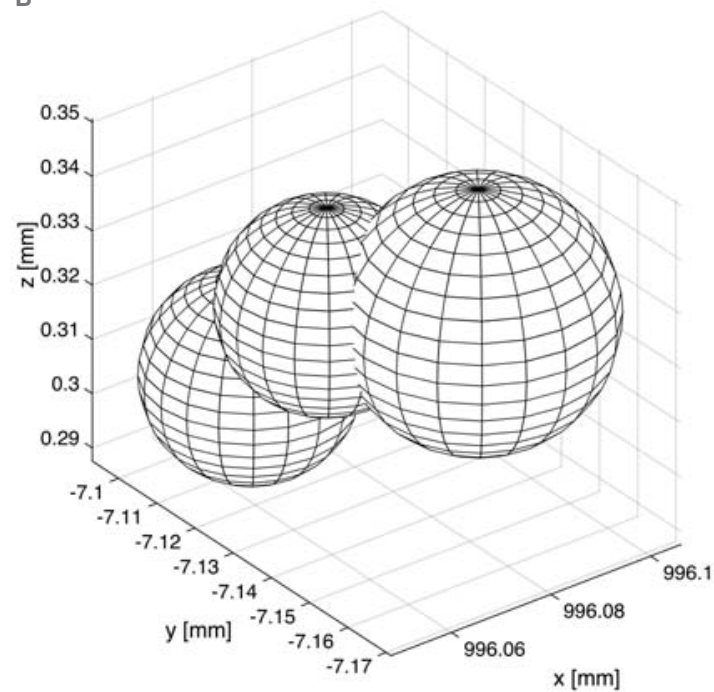

D

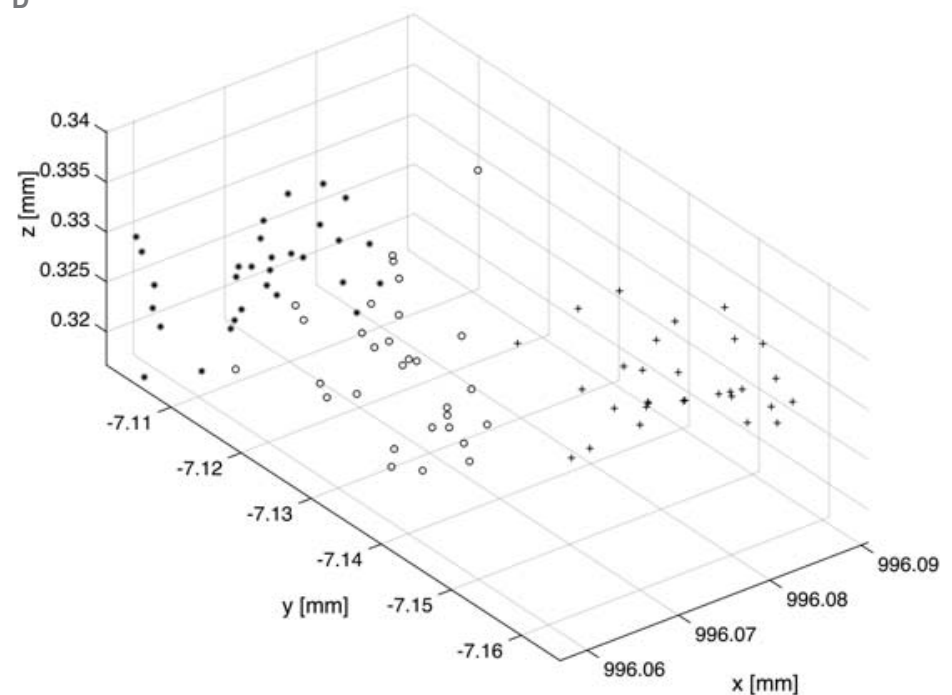

Fig. 9. Distribution of the attained end-effector's positions in terms of the approach direction for measuring points (A.) No. 1, (B.) No. 2,

(C.) No. 3, and (D.) No. 2

Rys. 9. Rozkład przestrzenny osiągniętych pozycji chwytaka/narzędzia w zależności o kierunku zbliżania do punktów pomiarowych (A.) nr 1, (B.) nr 2,

(C.) $n$ r 3 i (D.) nr 2

\subsection{Estimation of RP for results of measurement with use of the laser tracker}

The carried out measurement was repeated with use of the laser tracker (Leica AT 401), and RP was estimated once more. The same robot program (command poses and sequences of approaches) and RP value estimation procedure were used. The achieved estimates of RP are listed in tab. 4.

The values of RP listed in tab. 4 were of the same order of magnitude but approximately $50 \%$ greater than that evaluated basing on measurement made with use of the low-cost stereovision system. The value of RP was overestimated (mean: $0.03 \mathrm{~mm}$, median: $0.031 \mathrm{~mm}$, and variation $80 \%$ of the mean). Despite the reported quantitative differences the considered RP estimates are of the order of magnitude of the reference value of RP.

The laser tracker, which, depending on type and installed software option, is approximately 3-10 times more expensive than the developed vision system, is considerably easier to be applied in conditions present in a robotic cell. It is also much more efficient due to automated calibration and
Tab. 4. Estimated values of the unidirectional positioning repeatability RP [mm] basing on the laser tracker measurement

Tab. 4. Wyestymowane wartości jednokierunkowej powtarzalności pozycjonowania RP [mm] wyznaczone na podstawie pomiaru trakerem laserowym

\begin{tabular}{|c|c|c|c|}
\hline Approach directions & $\mathrm{x}$ & $\mathrm{y}$ & $\mathrm{z}$ \\
\hline Point No. 1 & 0.026 & 0.031 & 0.016 \\
\hline Point No. 2 & 0.025 & 0.032 & 0.035 \\
\hline Point No. 3 & 0.030 & 0.034 & 0.040 \\
\hline
\end{tabular}

position estimation procedures. Additionally, the tracker provides possibility of measurement during motion with tracking of the object, what is not available for the low-cost vision system. 
Regarding the achieved reasonable estimation of $\mathrm{RP}=0.02 \mathrm{~mm}$ with the measurement system of approximately $0.1 \mathrm{~mm}$ accuracy, the authors suppose that it was a result of the random measurement noise and of the random dispersion of the positions measured during the consequent approaches to the command pose. In the procedure of determination of RP the estimates of parameters (mean and standard deviation) of random distribution of the measured positions were used, not the actual distances between the recorded positions, what could cause that the value of RP corresponding to the resolution of the measuring system was effectively estimated.

\section{Summary}

In the paper, the authors focused on application of the exemplary low-cost vision system to determination of the manipulator end-effector's position. The carried out analysis comprised:

- assessment of properties of spatial distribution of the measurement results,

- theoretical calculation based assessment of position measurement error,

- the experimental data based determination of the tested manipulator end-effector's local estimates of positioning repeatability RP and multidirectional positioning accuracy $v A P$.

The theoretical analysis led to determination of the resolution of the measurement system of order of magnitude of $0.01 \mathrm{~mm}$. The obtained results indicated that the tested measurement system could be recommended to position measurement with the demanded accuracy of $0.1 \mathrm{~mm}$.

Surprisingly, the experimental analysis led to estimation of $\mathrm{RP}$ value, which was very close to the robot manufacturer's reference value $(0.02 \mathrm{~mm})$.

The main benefit of use of the considered low-cost system is obviously the cost saving. Additionally, the open structure of the system's hardware and software makes possibility of easy introduction of required modifications.

The main drawback of the considered system is the testing complexity and time-consuming preparation of measurement as well as of experimental data analysis. One of the most time-consuming steps is the calibration of cameras, though there are reported the trials to speed-up this procedure by automation [5]. The measurement in various, distant parts of a robot workspace requires manual rearrangement of the measurement set-up, what is also time consuming. On the other hand it is possible to assemble the cameras to the dedicated fixture. This would provide no need of repeating calibration after redirecting the vision system to another object.

Some steps of the procedure are considerably operator dependent (e.g. selection of parameters of processing) who must have sufficient knowledge to make the proper choice.

Additional disadvantages like necessity of placement of markers on the tested structure (e.g. a manipulator), which during removal may damage the surface of the structure or may leave stains of glue after removal should be also considered.

Taking into account the mentioned above benefits and disadvantages, the considered low-cost vision system is recommended rather for occasional application by experienced users or for auto calibration, than for standard services or usage as a portable measuring system.

Regarding the future investigation, the authors think that it would be interesting to assess how much determination of orientation together with position would influence complexity of the experimental procedure, and if it would improve effectiveness of the considered system when compared with more sophisticated and costly measurement systems.

\section{Acknowledgements}

The research reported in this paper has been financed from the state budget for science. The authors wish to acknowledge Wojciech Kusak and Dawid Gurgul for participation in the reported experiments. The authors wish to thank RCC NOVA for possibility of use the company's laser tracker in the course of the conducted research.

\section{References}

1. Abderrahim M., Khamis A., Garrido S., Moreno L., Accuracy and calibration issues of industrial manipulators, in Industrial robotics: programming, simulation and application, Ed. Low K.-H., plV pro literatur Verlag Robert Mayer-Scholz, 2007, 131-146, DOI: 10.5772/4895.

2. Batchelor B.G. Ed., Machine Vision Handbook, Springer-Verlag 2012.

3. Cyganek B., Siebert J.P., An Introduction to 3D Computer Vision Techniques and Algorithms, 2009.

4. Du G. Zhang P., Online robot calibration based on vision measurement, "Robotics and Computer-Integrated Manufacturing", Vol. 29, Issue 6, 2013, 484-492, DOI: 10.1016/j. rcim.2013.05.003.

5. Garbacz P., Mizak W., A novel approach for automation of stereo camera calibration process, „Pomiary Automatyka Robotyka", Vol. 17, No. 2/2013, 234-238.

6. Hartley R., Zisserman A., Multiple View Geometry in Computer Vision, Cambridge Univ. Press, 2004.

7. ISO 9283:1998 Manipulating industrial robots - Performance criteria and related test methods.

8. Kohut P., Metody wizyjne w robotyce (cz. 2), Vision methods in robotics, (part II), „Przegląd Spawalnictwa”, Stowarzyszenie Inżynierów i Techników Mechaników Polskich, R. 81, Nr 1, 2009, 31-38.

9. Kohut P., Mechatronics systems supported by vision techniques, "Solid State Phenomena", Vol. 196, 2013, 62-73, DOI: 10.4028/www.scientific.net/SSP.196.62.

10. Kusak W., Testing of positioning repeatability of a manipulator (in Polish), Bachelor thesis, WIMIR AGH-UST, Krakow, Poland 2014.

11. Ma Y., Soatto S., Kostecka J., Sastry S., An invitation to $3 D$ Vision, Springer-Verlag, New York 2004.

12. Mendenhall W., Scheaffer E.L., Wackerly D.D., Mathematical statistics with applications, Duxbury Press 1986.

13. Svaco M., Sekoranja B., Suligoj F., Jerbic B., Calibration of an industrial robot using stereo vision system, $24^{\text {th }}$ DAAAM International Symposium on Intelligent Manufacturing and Automation, 2013, 459-463.

14. TEMA user's guide, Image Systems AB, 2011.

15. Trucco E., Verri A., Introductory Techniques for $3 D$ Computer Vision, Prentice-Hall, Upper Saddle River, New Jersey, 1998.

16. Zhang Z., A flexible new technique for camera calibration, IEEE Transactions on Pattern Analysis and Machine Intelligence, Vol.22, Issue 11, 2000, 1330-1334, $10.1109 / 34.888718$. 


\section{Niskokosztowy system wizyjny do wyznaczenia pozycji chwytaka robota}

Streszczenie: Systemy wizyjne są powszechnie stosowane w robotyce. Najczęściej pełnią rolę układów sensorycznych, chociaż mogą być też użyte do pomiaru pozycji chwytaka/narzędzia robota. W artykule przestawiono przykład zastosowania niskokosztowego systemu wizyjnego do pomiaru położenia chwytaka. Wykorzystany system wizyjny składał się z pary aparatów z matrycą CMOS. Przeprowadzony eksperyment polegał na rejestracji serii statycznych obrazów po dojściu chwytaka robota (przenoszącego sześcian wzorcowy z zestawem markerów) do pozycji zadanej, powtarzalnie z tego samego kierunku. Analiza precyzji wyznaczania pozycji sześcianu wzorcowego obejmowała: wyznaczenie rozkładu przestrzennego kolejnych pozycji sześcianu, oceny jakości zarejestrowanych obrazów za pomocą 4 kryteriów oraz porównania techniki pomiarowej wykorzystującej rozważany układ wizyjny i profesjonalny system pomiarowy ( $w$ tym celu powtórzono pomiar z wykorzystaniem trakera laserowego i lokalnie wyestymowano jednokierunkową powtarzalność pozycjonowania - RP). Analiza wyników przeprowadzonych badań pokazała, że niskokosztowy system stereowizyjny może być pomyślnie zastosowany do pomiaru położenia chwytaka robota z dokładnością około 0,1 mm. Taka dokładność jest często wystarczająca w warunkach przemysłowych. Dodatkowo, wyniki pomiaru pozwoliły dobrze oszacować powtarzalność pozycjonowania robota RP, która dla typu wykorzystanego robota wynosi $0,02 \mathrm{~m}$.

Słowa kluczowe: roboty manipulacyjne, systemy wizyjne, pomiar pozycji chwytaka/narzędzia, powtarzalność pozycjonowania Słowa kluczowe: roboty manipulacyne, systemy

\section{Wojciech Lisowski \\ lisowski@agh.edu.pl}

Master of Mechanical Engineering, PhD in Automatic Control and Robotics, DSC in Mechanics. Since 1987 a researcher at AGH University of Science and Technology. His research interests focus on mechanics and analysis of precision of manipulators, off-line robot programming as well as on experimental investigation of vibration and structural dynamics.

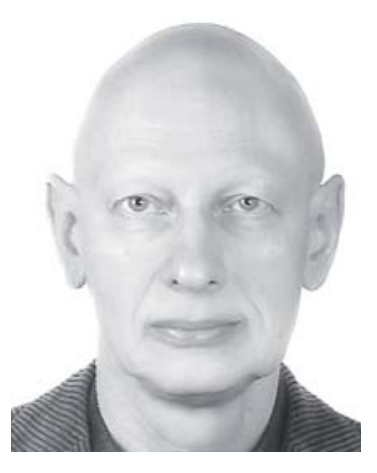

\section{Piotr Kohut \\ pko@agh.edu.pl}

He received PhD degree in Automatic Control and Robotics from Faculty of Mechanical Engineering and Robotics, AGH University of Science and Technology, Poland, in 2002. Now he works at Department of Robotics and Mechatronics. His scientific interests focus on mechatronics, vision systems, methods of image processing and analysis, 3D measurement techniques.

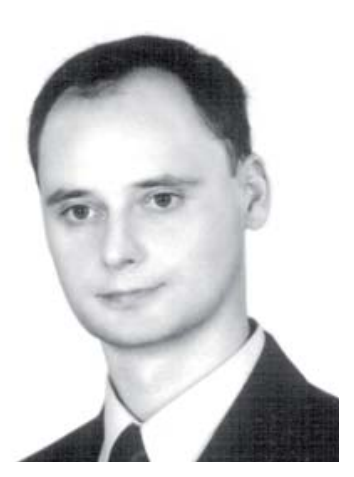

